\section{Kidney \\ Blood Pressure Research}

\title{
Urotensin II Induces ER Stress and EMT and Increase Extracellular Matrix Production in Renal Tubular Epithelial Cell in Early Diabetic Mice
}

\author{
Xin-Xin Pang ${ }^{\mathrm{a}}$ Qiong Bai ${ }^{\mathrm{a}} \quad$ Fei Wu ${ }^{\mathrm{a}}$ Guan-Jong Chen ${ }^{\mathrm{a}} \quad$ Ai-Hua Zhang ${ }^{\mathrm{a}}$ \\ Chao-Shu Tang ${ }^{b}$
}

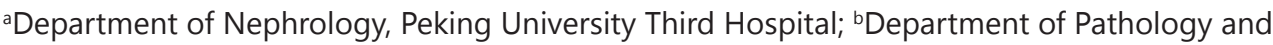
Physiology, Peking University Health Science Center, Beijing, China

\section{Key Words}

Urotensin II • Diabetic Nephropathy • EMT • Endoplasmic reticulum stress

\begin{abstract}
Background/Aims: Urotensin II (UII) and its receptor are highly expressed in the kidney tissue of patients with diabetic nephropathy (DN). The aim of this study is to examine the roles of UII in the induction of endoplasmic reticulum stress (ER stress) and Epithelial-mesenchymal transition (EMT) in DN in vivo and in vitro. Methods: Kidney tissues were collected from patients with DN. C57BL/6 mice and mice with UII receptor knock out were injected with two consecutive doses of streptozotocin to induce diabetes and were sacrificed at $3^{\text {th }}$ week for in vivo study. HK-2 cells in vitro were cultured and treated with UII. Markers of ER stress and EMT, fibronectin and type IV collagen were detected by immunohistochemistry, real time PCR and western blot. Results: We found that the expressions of protein of UII, GRP78, CHOP, ALPHA-SMA, fibronectin and type IV collagen were upregulated while E-cadherin protein was downregulated as shown by immunohistochemistry or western blot analysis in kidney of diabetic mice in comparison to normal control; moreover expressions of GRP78, CHOP, ALPHA-SMA, fibronectin and type IV collagen were inhibited while E-caherin expression was enhanced in kidney in diabetic mice with UII receptor knock out in comparison to C57BL/6 diabetic mice. In HK-2 cells, UII induced upregulation of GRP78, CHOP, ALPHA-SMA, fibroblastspecific protein 1(FSP-1), fibronectin and type collagen and downregulation of E-cadherin. UII receptor antagonist can block UII-induced ER stress and EMT; moreover, 4-PBA can inhibit the mRNA expression of ALPHA-SMA and FSP1 induced by UII in HK-2 cells. Conclusions: We are the first to verify UII induces ER stress and EMT and increase extracellular matrix production in renal tubular epithelial cell in early diabetic mice. Moreover, UII may induce renal tubular
\end{abstract}




\section{Kidney Blood Pressure Research}

epithelial EMT via triggering ER stress pathway in vitro, which might be the new pathogenic pathway for the development of renal fibrosis in DN.

\section{Introduction}

Pathogenesis of diabetic nephropathy (DN) is unclear [1]. Despite strict control of blood glucose, cholesterol level, and blood pressure, many DN patients still progress to end stage renal disease. The DN patients with end stage renal disease are a testament that the current treatment available for DN is limited and not entirely effective. To develop better treatment for DN, it is important to recognize new pathogenic factors and new pathogenesis model for DN.

The endoplasmic reticulum plays an important role in the maintenance of protein homeostasis. Endoplasmic reticulum (ER) stress is defined as the accumulation of unfolded or misfolded proteins in the lumen of the ER [2]. A number of physiological and pathological conditions, such as hypoxia, glucose depletion, and oxidative stress are able to disturb proper endoplasmic reticulum function and thereby cause ER stress [2]. It has been found that ER stress occurred in podocytes and tubular epithelial cells [3,4]. However, the mechanism that ER stress induces renal fibrosis is still unclear. Epithelial-mesenchymal transition (EMT) also plays a pivotal role in renal fibrosis. Additionally, ER stress could induce EMT in thyroid gland cells and alveolar epithelial cells [5, 6].

Army, et al. first reported urotensin II (UII) as an 11-amino acid vasoactive peptide. It is the ligand of G protein-coupled receptor 14 (GPR14), a receptor of UII (also named UT) [7]. Robyn, et al found that UII and its receptor are highly expressed in the kidney tissue of patients with diabetic nephropathy [8]. Therefore, we presume that UII may play important roles in the development of diabetic nephropathy. Moreover, UII binds with its receptor and triggers phospholipidase $C$ activation and inositol 1, 4, 5 triphosphate receptors-dependent pathways, which induces calcium to release from endoplasmic-reticulum [9]. Mekahli et al. also found that the depletion of endoplasmic-reticulum calcium was associated with ER stress [10]. Since both UII and ER stress are associated with lowered calcium concentration in endoplasmic-reticulum, we speculate that UII may also be correlated with ER stress in its role in the development of DN.

In our current study, we aim to study whether UII can induce ER Stress and EMT, and increase extracellular matrix production in renal tubular epithelial cell in diabetes by in vitro study and in vivo study.

\section{Materials and Methods}

\section{Histological study of renal biopsy tissue of patients}

Histological studies were performed on renal biopsy tissues obtained from 10 diabetic nephropathy patients and 10 healthy subjects. The DN tissues were obtained from DN patients with type 2 diabetes who underwent diagnostic procedures. The healthy control kidney tissues were obtained from patients who underwent nephrectomy as part of their tumor treatment. All healthy control patients have normal renal function, normal blood pressure, and normal urine routine test. All participants signed their written informed consents, and the study was approved by the medical ethic committee at Peking University Third Hospital. In all cases, the underlying histological state represented typical changes of DN and normal control kidney tissue. Renal biopsy tissue was fixed in neutral buffered formalin and embedded in paraffin. Then, they were stained by PAS, PASM, and Masson. After staining, they were studied by light microscopy, electron microscopy and immunofluorescence.

Immunohistochemical staining for renal tissue of patients and mice

Histological studies were performed on renal tissues of patients and mice. The renal tissues were 


\section{Kidney Blood Pressure Research}

embedded in optimal cutting temperature compound. The tissues were sectioned at a thickness of $10 \mu \mathrm{m}$. For immunohistochemical analysis, 5\% hydrogen peroxide was used to deplete endogenous peroxidase activity. Following pre-incubation with $5 \%$ bovine serum albumin for $30 \mathrm{~min}$ to prevent nonspecific staining, the sections were incubated with primary rabbit or mice polyclonal anti-UII $(1: 100$, ab194676, Abcam, Shanghai, China), anti-GPR14 (1:100, ab150584, Abcam, Shanghai, China), anti-GPR78 (1:100, ab21685, Abcam, Shanghai, China), anti-CHOP (1:100, ab11419, Abcam, Shanghai, China), anti-ALPHA-SMA (1:300, bs-10196R, Bioss, Beijing, China), anti-E-cadherin (1:100, ab76055, Abcam, Shanghai, China), anti-type IV collagen (1:500, ab6586, Abcam, Shanghai, China), and anti-fibronectin (1:250, ab2413, Abcam, Shanghai, China) overnight at $4{ }^{\circ} \mathrm{C}$.

The sections were then incubated with horseradish peroxidase (HRP)-conjugated anti-rabbit or anti-mouse IgG antibodies (Zhongshan Gold Bridge Biotechnology Co., Ltd Beijing, China) for $30 \mathrm{~min} 37$ ${ }^{\circ} \mathrm{C}$. The peroxidase was visualized by incubation with 3, 3'-diaminobenzidine (DAB) in the dark for $1 \mathrm{~min}$ for antibody. The sections were counterstained with hematoxylin, dehydrated, and observed under a light microscope. Negative controls were established using PBS as a substitute for the primary antibody. Positive staining was indicated by brown deposits. For semi quantitative analysis, 10 high-power microscope fields were randomly selected, and the pathological image analysis system was used to calculate the integral optical density (IOD) of positive staining for UII, GPR14, CHOP and GRP78 in diabetic nephropathy patients.

\section{Animal model system}

The UII receptor knock-out mouse strain used for this research project was created from ES cell clone 12922A-B6, generated by Regeneron Pharmaceuticals, Inc. and made into live mice by the KOMP Repository (www.komp.org) and the Mouse Biology Program (www.mousebiology.org) at the University of California Davis. The mouse was backcrossed onto C57BL/6 background. Wild type C57BL/6 mice were purchased from a local animal facility (Vital River Laboratory Animal Technology Co. Ltd., Beijing, China). Experiments were performed on 15 UII receptor knock-out (UTKO) male mice and 30 wild type male mice between 8 and 10 weeks of age and weighed between 20 and 25 grams. The mice were housed under standard condition and were individually caged. The mice were divided into three groups. 15 knock-out mice and 15 wild type mice were placed in the experimental group and another 15 mice were placed in the normal control group. The animals were fasted overnight before induction of diabetes with streptozotocin (STZ) but had free access to drinking water. Diabetic mice were randomly killed at 3rd week after the onset of diabetes. The experimental protocols were approved by the Biological Medical Ethics Committee of the Peking University Health Science Center (Number LA 2013-47).

Diabetes was induced by a single intraperitoneal injection of $125 \mathrm{mg} / \mathrm{kg}$ body weight streptozotocin (STZ) (Amresco LLC Solon, OH, USA) that was freshly dissolved in $0.1 \mathrm{~mol} / \mathrm{l}$ citrate buffer at $\mathrm{pH} 4.5$. The plasma glucose in all diagnosed diabetic mice, examined $72 \mathrm{~h}$ after STZ injection, was higher than 16.7 $\mathrm{mmol} / \mathrm{l}$. Control mice were injected with an equal volume of $0.1 \mathrm{~mol} / \mathrm{l}$ citrate buffer.

\section{UT knocks out mice design}

The UT gene knout out (KO) mouse strain used for this research project was created from ES cell clone 12922A-B6, generated by Regeneron Pharmaceuticals, Inc. and made into live mice by the KOMP Repository (WWW.KOMP.org) and the Mouse Biology Program (www.mousebiology.org) at the University of California Davis. Then the four heterozygous male mice were imported to Peking University Third Hospital, and matched and rotated with young female C57BL6 mice, and bred eight generations, PCR Male heterozygous were crossed with C57B1/6 females to give N1F0 offspring, which were subsequently intercrossed to generate $\mathrm{N} 1 \mathrm{~F} 1$ offspring. In addition, NEFF offspring were successively backcrossed to C57B1/6 females to generate N5F0 mice. These were intercrossed to create an N5F1 population. Genotyping of study populations N1F1 and N5F1 study populations were genotyped by polymerase chain reaction (PCR) of genomic DNA isolated from the toes of animals.

\section{Genotype Identification}

According to the Mouse Biology Program, University of California Davis,

Primers of Reg-NeoF: 5'-GCAGCCTCTGTTCCACATACACTTCA-3',

Reg-UT-R: 5'-CTCTCAGATCTCTCAGCTACCTGCC-3', 


\section{Kidney Blood Pressure Research}

Reg-UT-wtR: 5'-CTTGAAGGAAGCTTGCTGGGATAGC-3', Reg-UT-wtF: 5'-ATTGGGCTGCTCTATATCCGTCTGG-3',

Genotype Forward Primer Reverse Primer Amplicon size (bp): Knockout Reg-NeoF Reg-UT-R 756bp; Wild type Reg-UT-wtF Reg-UT-wtR 63bp,

Toe of newborn mice within 6 weeks were cut for DNA extraction (DNA extraction kit, D3396-01 OMEGA) . Mouse PCR Protocol, Reagent $1 \mathrm{X}(\mu \mathrm{L})$, water (biological grade) $10.725 \mu \mathrm{L}$, betain $5 \mathrm{M}$ (Sigma) $6.5 \mu \mathrm{L}$, DMSO (Sigma) $0.325 \mu \mathrm{L}, 25 \mathrm{mM} \mathrm{MgCl} 2$ (AB) $1.75 \mu \mathrm{L}, 10 \mathrm{mM}$ dNTPs (Invitrogen) $0.5 \mu \mathrm{L}$, primers $(20 \mu \mathrm{M}$ each) $0.5 \mu \mathrm{L}$, Taq $5 \mathrm{U} / \mu \mathrm{L}$ (AmpliTaq, $\mathrm{AB}) 0.2 \mu \mathrm{L}$, total cocktail $23 \mu \mathrm{L}$, template $2 \mu \mathrm{L}$, reaction volume $25 \mu \mathrm{L}$, Cycling Parameters: Temperature $94^{\circ} \mathrm{C}$ for $5 \mathrm{~min}, 94{ }^{\circ} \mathrm{C}$ for $15 \mathrm{sec}, 65^{\circ} \mathrm{C}$ for $30 \mathrm{sec} 10 \mathrm{X}$ (decrease $1^{\circ} \mathrm{C} / \mathrm{cycle}$ ), $72^{\circ} \mathrm{C}$ for $40 \mathrm{sec}, 94^{\circ} \mathrm{C}$ for $15 \mathrm{sec}, 55^{\circ} \mathrm{C}$ for $30 \mathrm{sec} 30 \mathrm{X}, 72^{\circ} \mathrm{C}$ for $40 \mathrm{sec}, 72^{\circ} \mathrm{C}$ for $5 \mathrm{~min}$, $4{ }^{\circ} \mathrm{C}$ finished.

Amplification 756 bp means urotensin II receptor knocked out and 63bp means wild type, both 756bp and 63bp show up means heterozygote of UT knock out, alone756 bp show up means homozygote of UT knock out (KO mice) genotype. Then mRNA and protein expression of UT in kidney in KO group and were performed by real time PCR and western blot.

\section{Phenotypic Analysis}

Blood glucose, blood pressure is tested using method described above. Blood samples are obtained to perform blood routine examination.

\section{Cell culture studies}

Renal proximal tubular epithelial cell lines HK-2 (human) were used. HK-2 cells were obtained from ATCC (Rockville, MD). Cells were grown in DMEM/F12 media (Hyclone,Beijing,China) supplemented with $10 \%$ FBS (Biological Industries, Israel ) at $37^{\circ} \mathrm{C}$ and $100 \mathrm{U} / \mathrm{ml}$ antibiotics in a humidified incubator (5\% CO2, 95\% air). The HK-2 cell suspensions were plated on tissue flasks. After trypsinization, cells were then incubated in DMEM with 0.5\% FBS for $24 \mathrm{~h}$ and then treated with UII (Sigma, St. Louis, MO, USA) at the concentrations of $10^{-5} \mathrm{~mol} / \mathrm{l}, 10^{-6} \mathrm{~mol} / \mathrm{l}, 10^{-7} \mathrm{~mol} / \mathrm{l}, 10^{-8} \mathrm{~mol} / \mathrm{l}$, and $10^{-9} \mathrm{~mol} / \mathrm{l}$ for $12 \mathrm{~h}-24 \mathrm{~h}$, UII combined with UII receptor antagonist SB657510 (Phoenix Biotech Co. LTD) $10^{-6} \mathrm{~mol} / \mathrm{l}$, or UII combined with 4-phenylbutyric acid (4-PBA) (ER Stress inhibitor) (Sigma, St. Louis, MO, USA) $(0.1,1 \mathrm{mM}$ ) for various time periods (12, 24 hours), the cells were treated with ER inducer tunicamycin (TM) $25 \mathrm{ng} / \mathrm{ml}$ as ER Stress positive control or high glucose $(30 \mathrm{mmol} / \mathrm{l})$ as EMT positive control. In vitro cell experiments, we repeated independently the test for three times.

\section{Western blot analysis for cell and renal tissue of mice}

Proteins were extracted from HK-2 cells and renal tissues of mice. Western blot analysis of UII, GRP78, CHOP, ALPHA-SMA, fibroblast-specific protein 1(FSP-1) and E-cadherin were performed. Briefly, the protein samples were denatured at $95{ }^{\circ} \mathrm{C}$ for 5 min separated on a $10 \%$ SDS-PAGE gel prior to being transferred to NC membranes (Applygen Technologies Inc. Beijing, China). Membranes were subsequently incubated with primary rabbit or mice polyclonal anti-UII, anti-GRP78, anti-ALPHASMA, anti-E-cadherin, and anti- $\beta$-actin 1:500,bs2918, Bioworld Technology, Nanjing; 1:1000,ab21685, Abcam, Shanghai, China; 1:500,bs-10196R,Bioss,Beijing,China; 1:1000,ab76055,Abcam, Shanghai, China; 1:500,TA-09, Zhongshan Gold Bridge Biotechnology Co., Ltd Beijing, China) overnight at $4{ }^{\circ} \mathrm{C}$, followed by incubation with conjugated goat (polyclonal) anti-rabbit or anti-mouse IgG (1:10000, IRDye 800CW Li-Cor, Nebraska, USA). Semi-quantitative grayscale intensity was generated with Odyssey Software v 1.2.

Quantitative real-time PCR analysis for kidney tissues and cells

The mRNA expression of the genes involved in ER stress and EMT was measured using quantitative real-time polymerase chain reaction (PCR). The total RNA was prepared using Trizol reagent (Invitrogen) according to the manufacturer's protocol. The quantity and purity of RNA were assessed by absorbance at 260 and $280 \mathrm{~nm}$. The cDNA was prepared from the total RNA with reverse transcriptase (RT) Primer Mix using Prime Script RT reagent Kit With cDNA Eraser according to the manufacturer's instruction. The primers for real-time PCR analysis were as follows: 


\section{Kidney Blood Pressure Research}

Kidney Blood Press Res 2016;41:434-449

DOI: 10.1159/000443445

Published online: July 13, 2016

(C) 2016 The Author(s). Published by S. Karger AG, Base

www.karger.com/kbr

\author{
ALPHA-SMA (human) (forward) 5'GCCTTGGTGTGTGACAATGG-3' \\ and (reverse) 5'AAAACAGCCCTGGGAGCAT-3', \\ FSP1 (human) (forward) 5'GCTTCTTCTTTCTTGGTTTG-3' \\ and (reverse) 5'CTCCTTTAGTTCTGACTTGTTG-3', \\ GRP78 (human) (forward) 5'CATCACGCCGTCCTATGTCG-3' \\ and (reverse) 5'CGTCAAAGACCGTGTTCTCG-3', \\ CHOP (human) (forward) 5'GGAAACAGAGTGGTCATTCCC-3' \\ and (reverse) 5'CTGCTTGAGCCGTTCATTCTC-3', \\ GAPDH (human) (forward) 5'ACAACTTTGGTATCGTGGAAGG-3' \\ and (reverse) 5'GCCATCACGCCACAGTTTC-3'. \\ Urotensin II (mouse) (forward) 5'GAGGAAGGCTTTCGCTGGGCA-3' \\ and (reverse) 5'GGGCAGCCCCGTGTTGCTTA-3' \\ ALPHA-SMA (mouse) (forward) 5' CTGACAGAGGCAACCACTGAA -3' \\ and (reverse) 5' CATCTCCAGAGTCCAGCACA -3' \\ E cadherin (mouse) (forward) 5' CAGGTCTCCTCATGGCTTTGC-3' \\ and (reverse) 5' CTTCCGAAAAGAAGGCTGTCC-3' \\ GRP78 (mouse) (forward) 5' TCATCGGACGCACTTGGAA-3' \\ and (reverse) 5' AACCACCTTGAATGGCAAGAA-3' \\ Fibronectin (mouse) (forward) 5' CACGGAGGCCACCATTACT-3' \\ and (reverse) 5' CTTCAGGGCAATGACGTAGAT-3' \\ IV collagen (mouse) (forward) 5' TTAAAGGACTCCAGGGACCAC-3' \\ and (reverse) 5' CCCACTGAGCCCTGTCACAC-3' \\ GAPDH (mouse) (forward) 5' GCACCACCAACTGCTTAGC-3' \\ and (reverse) 5' TCTTCTGGGTGGCAGTGATG-3'
}

The subsequent PCR amplification was carried out on a Light Cycler 2.0 system using 40 cycles of $95{ }^{\circ} \mathrm{C}$ for $30 \mathrm{~s}, 58{ }^{\circ} \mathrm{C}$ for $15 \mathrm{~s}$ and $72{ }^{\circ} \mathrm{C}$ for $10 \mathrm{~s}$. GAPDH was used as an internal control. Fold changes, expressed as expressed as the mean $\pm \mathrm{SD}$, were calculated for the drug-treated groups versus the vehicle control using the $2^{-\Delta \Delta \mathrm{CT}}$ method.

Indirect immunofluorescence of cultured cells

Cells were fixed in $4 \%$ paraformaldehyde for 20 minutes at room temperature and were chilled in $\mathrm{pH}$ solution of 7.2-7.4.The cells were then rinsed 3 times with PBS. They were permeabilized with $0.5 \%$ Triton $\mathrm{X}-100$ in PBS at room temperature and were blocked in 5\% BSA for 30 minutes at room temperature and were incubated with primary antibody (Anti-ALPHA-SMA antibody 1:100,ab7817; Anti-E cadherin antibody 1:100,ab76055; Anti- Fibronectin antibody 1:100,ab2413) diluted in blocking buffer overnight at $4^{\circ} \mathrm{C}$.Then, the cells were incubated with $5 \mathrm{ug} / \mathrm{ml}$ Hoechst 33342 and secondary antibody (Alexa Flur ${ }^{\circledR}$ 488 label anti-mouse IgG,1:500, ZF-0512, Zhongshan Gold Bridge Biotechnology Co., Ltd Beijing, China or Alexa Fluor® 594 label anti-rabbit IgG,1:500,ZF-0516, Zhongshan Gold Bridge Biotechnology Co., Ltd Beijing, China) for 1 hours at room temperature. At last, we observed and took pictures in laser scanning confocal microscope.

\title{
Statistical analyses
}

All analyses were performed using SPSS 17.0. Results were reported as mean \pm standard deviation ( $\mathrm{x}$ $\pm \mathrm{s}$ ). Independent-samples t test or one way ANOVA test was applied in statistical analysis. P values below 0.05 were accepted to be significant.

\section{Results}

Renal morphologic changes of DN patients

The mean age in diabetic nephropathy patients was $52 \pm 15$ (years), male were 6 patients and female were 4 patients; mean systolic blood pressure was $147 \pm 14 \mathrm{mmHg}$; diastolic blood 


\section{Kidney Blood Pressure Research}

pressure was $88 \pm 11$ $\mathrm{mmHg}, 24$ hours protein excretion was 8.6 $\pm 3.5 \mathrm{~g}$; serum Alb was $32.3 \pm 6.2 \mathrm{~g} / \mathrm{L}$; HbA1C $6.6 \pm 0.6 \%$, serum creatinine (Scr) was $169 \pm 99 \mu \mathrm{mol} / \mathrm{L}$ Our diabetic patients' kidney biopsy showed mild to severe mesangial expansion, extracellular matrix increase, glomerular basement membrane thickening, and nodular sclerosis (Kimmelstiel-Wilson lesion). Predominance of global glomerulosclerosis, renal tubular atrophy, and interstitial fibrosis were also observed by PAS, Masson staining, PASM and electronic microscope test (Figure 1, A, B, C and D). The pathology of normal controls was also shown (Figure 1, E, F, G and H) ((image 400X light microscope, 5000X electronic microscope). Some patients' kidney pathology showed hypertensive benign arteriolar nephrosclerosis (ischemic glomerulosclerosis, renal tubular atrophy) besides typical diabetic nephropathy.

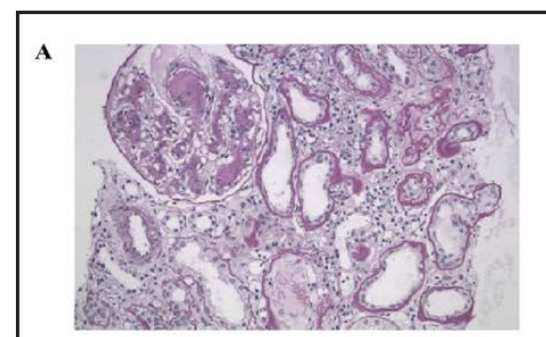

PAS (DN)

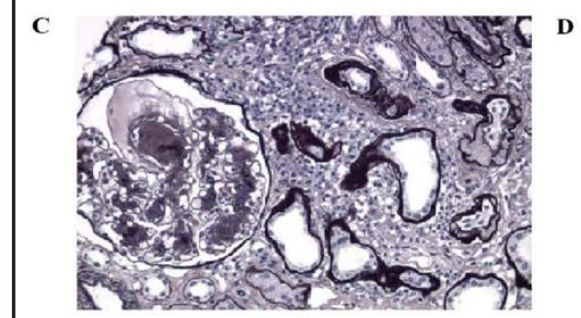

PASM (DN)

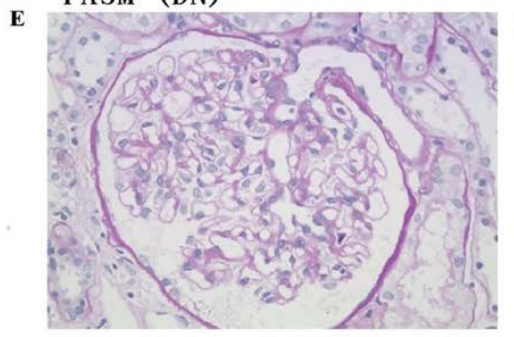

PAS (Normal control)
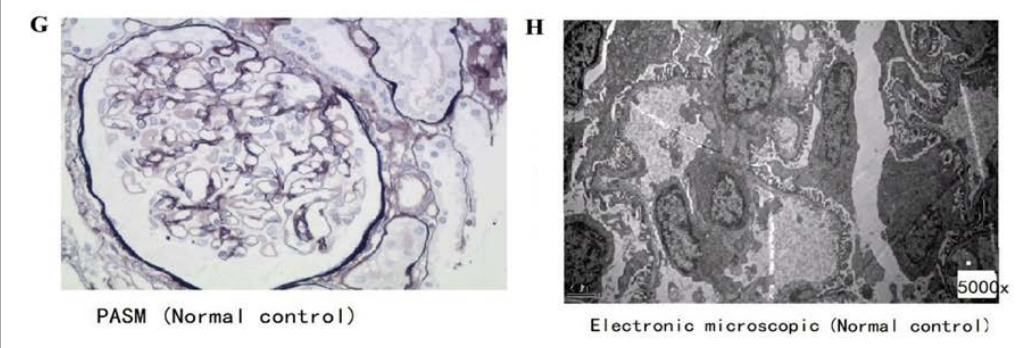

Fig. 1. The pathological examinations of kidney tissues. PAS staining of DN (A) and normal control (E), Masson staining of DN (B) and normal control (F), PASM staining of DN (C) and normal control (G), electronic microscope images of DN (D) and normal control were shown (image 400X light microscope, 5000X electronic microscope).

Immunohistochemistry analysis of UII, GPR14, GRP78 and CHOP in kidney tissue of diabetic nephropathy patients

UII (Figure 2, A) and GPR14 expressions (Figure 2, D) were consistently increased with increased expressions of ER stress markers, such as GRP78 (Figure 2, B) and CHOP (Figure $2, C$ ), in the kidney tissue of DN patients in comparison with that of normal control (Figure 2, A, B, C, D). Moreover, examination of UII and GPR14 proteins by immunohistochemical staining verified that both UII and GPR14 protein expressions were predominantly in the cytoplasm of renal tubular epithelial cells. (Figure 2, A, B, C, and D). Semi-quantitative 


\section{Kidney Blood Pressure Research}

Fig. 2. Expressions of UII, UII receptor, markers of ER Stress in kidney tissues. Expressions of UII (A ) , GRP78 (B) , CHOP ( C) and GPR14 (D) in DN patients and normal control were detected by immunochemistry and integral optical density value between DN group and normal control was compared, * $\mathrm{P}<0.05$ vs. Normal control group.

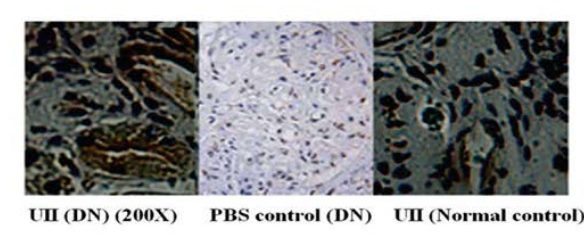

A

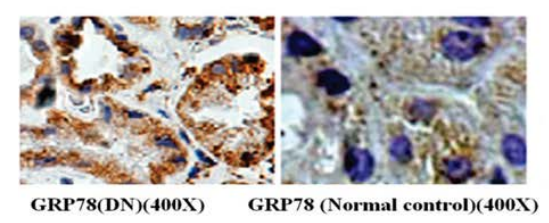

B

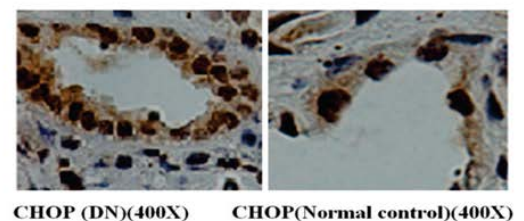

C
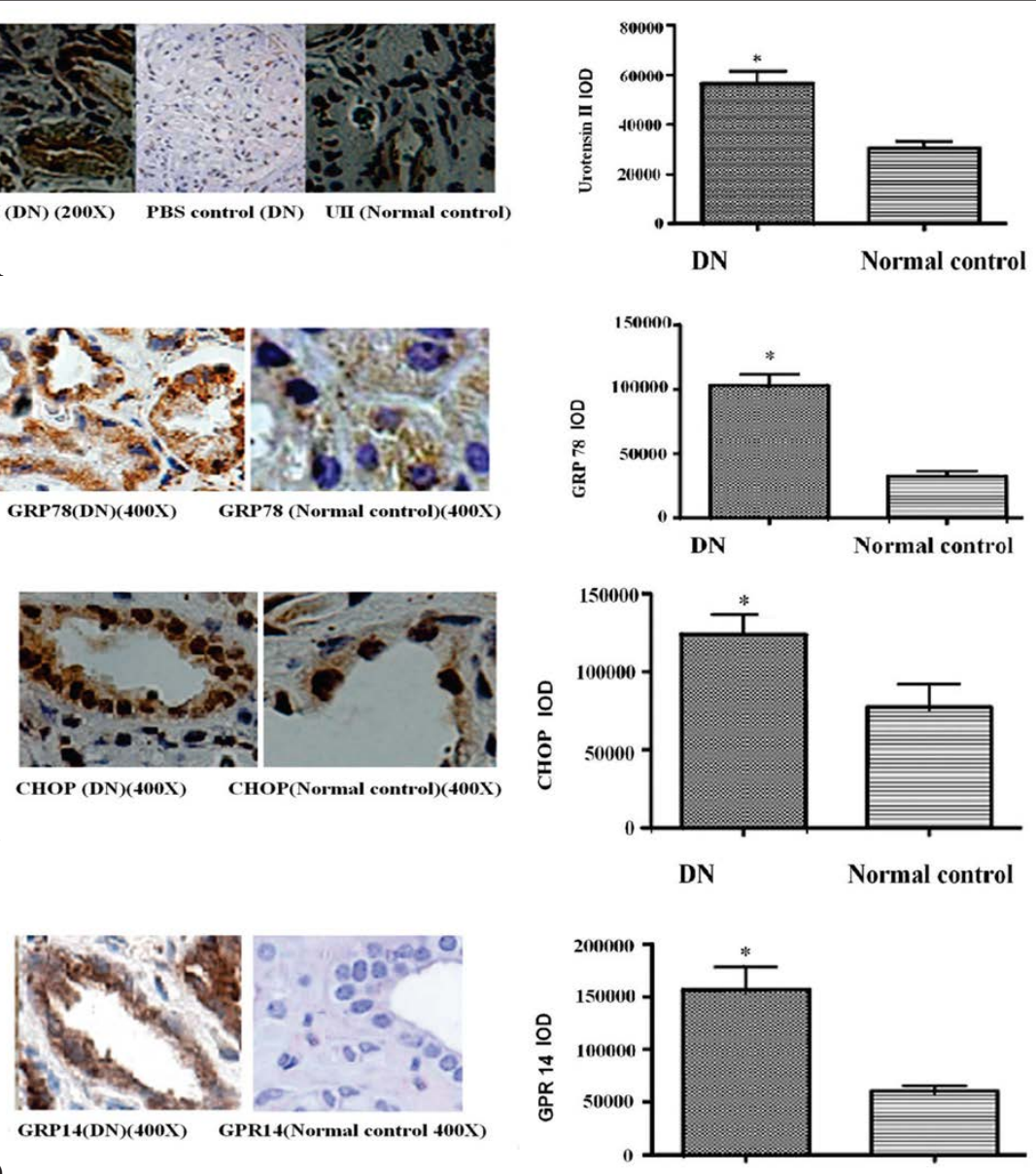

D

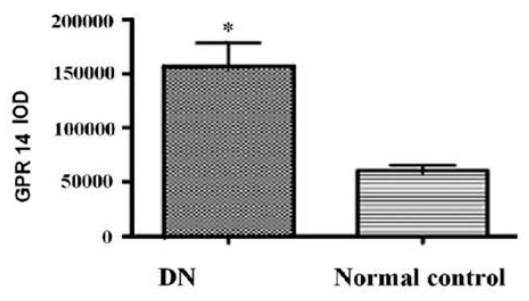

analysis of the intensity and area of UII and GPR14 staining showed that diabetes significantly increased UII, GPR14, GRP78, and CHOP protein expressions in comparison with that of normal controls. (Image 400X light microscope).

UII expression was negatively correlated with estimated glomerular filtrate rate (by MDRD formula) ( $\mathrm{r}=-0.666, \mathrm{P}=0.042$ ), positively correlated with 24 proteinuria excretion $(\mathrm{r}=0.699, \mathrm{P}=0.017)$.

\section{Genotyping of UT knock-out mice}

We generated homozygous UT knock-out mice for this study and confirmed its genotype through DNA extraction of its toe tissues with subsequent PCR analysis (Figure 3.A), moreover, mRNA and protein expression of UT in kidney in UT knockout mice (KO) were significantly decreased (figure 3.B, C) in comparison to wild type mice (WT). There were no significantly different in blood glucose, blood pressure between KO mice and WT mice.

Effect of UII on diabetes-induced expression of ER stress and EMT and production of extracellular matrix by immunochemistry and western blot

There were significantly higher fasting glucose in diabetes group (D) and diabetes with UT knock out group (UTKO+D) in comparison to normal control group (CTL). [26.6 $\pm 3.8(\mathrm{mmol} / \mathrm{L})$ Vs.25.8 $\pm 3.3(\mathrm{mmol} / \mathrm{L})$ Vs. $7.5 \pm 1.6(\mathrm{mmol} / \mathrm{L}), \mathrm{F}=75.933, \mathrm{P}=0.000)]$. Immunohistochemistry analysis and western blot analysis showed that expressions of UII, GRP78. CHOP (figure 4, A, B and C), ALPHA-SMA, (figure 5.A), type IV collagen, and fibronectin 


\section{Kidney Blood Pressure Research}

Fig. 3. Identification of genotyping UII receptor (UT) gene knock-out mice. UT gene knockout mice were identified by PCR (A), real time PCR (B) and western blot(C). Lane $\mathrm{N}$ is negative control without template DNA. Lane 1 and $2(+/+)$ represent wild type genotype (WT). Lane 3 (+/-) represents heterozygous UT knockout genotype. Lane

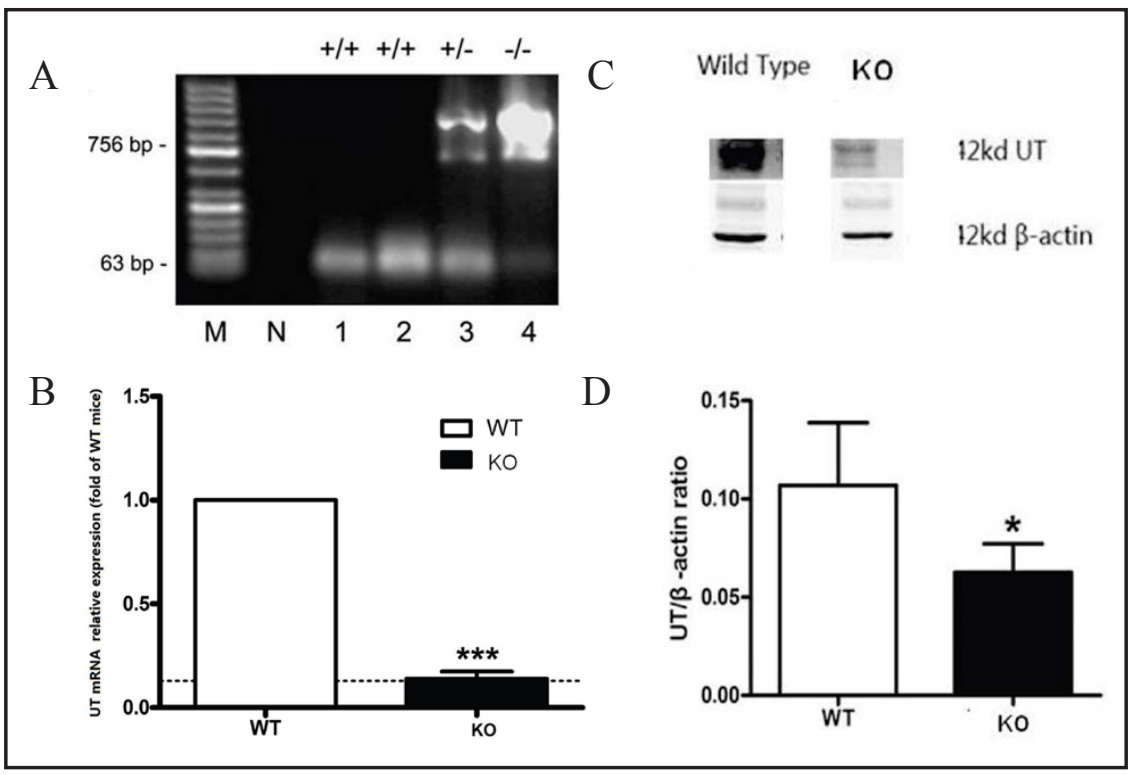
4 (-/-) represents homozygous UT knock-out genotype (KO mice). ${ }^{* * * *} \mathrm{P}<0.0001$ vs. mRNA expression of WT mice; ${ }^{*} \mathrm{P}<0.05$ vs. protein expression of WT mice.

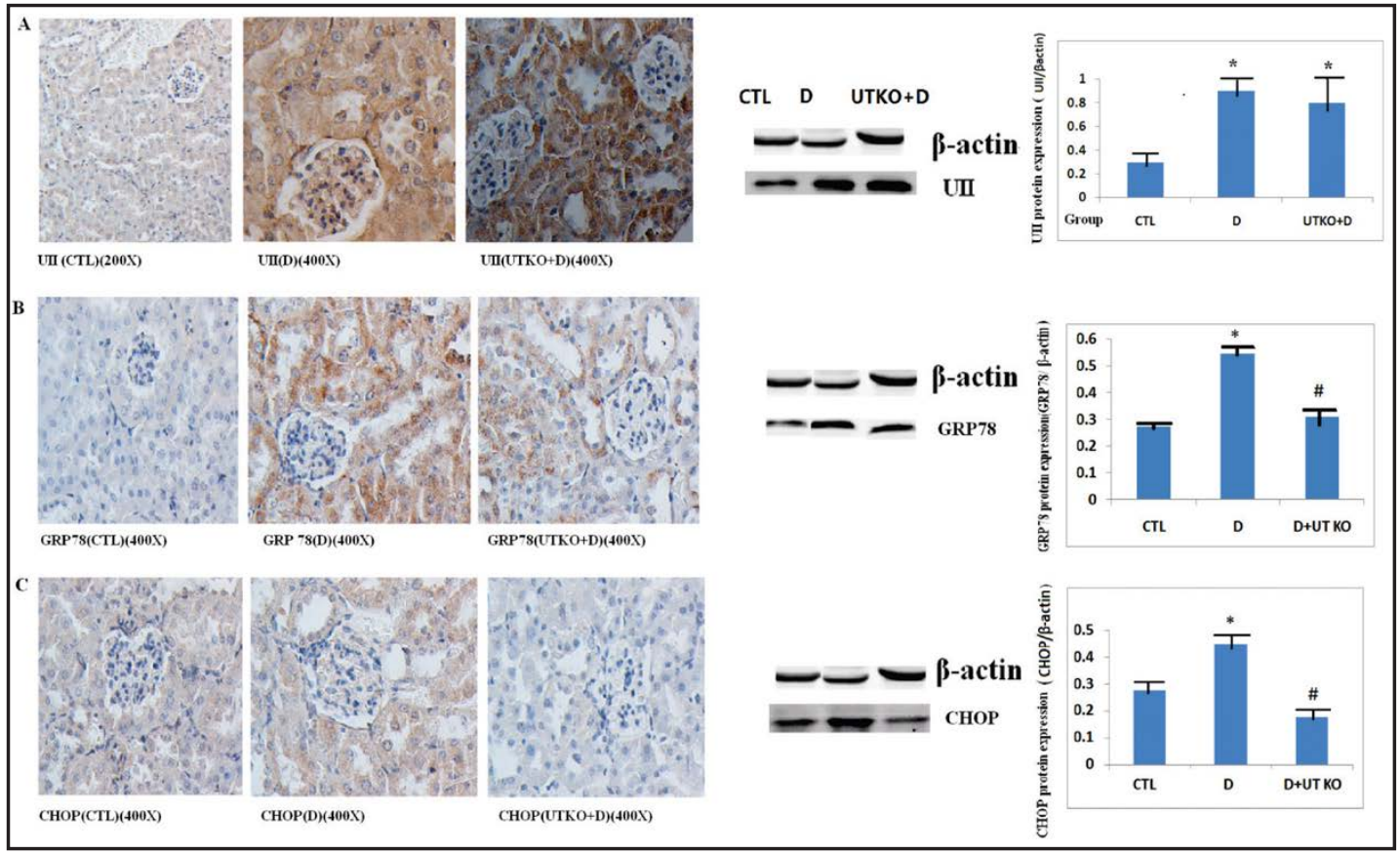

Fig. 4. Expressions of UII and markers of ER stress in kidney tissues. Expressions of UII (A), GRP 78(B) and CHOP (C) were detected by immunochemistry and western blot analysis, CTL: normal control mice, D: wild type diabetic mice, UTKO+D: diabetic mice with UII receptor knock out. ${ }^{*} \mathrm{P}<0.01$ vs.CTL group; \#P<0.05 vs. D group.

(figure 6. A.B) were highly increased in the kidney of D group whereas E-cadherin is drastically decreased (figure 5.B) in comparison to that of CTL group by immunochemistry and western blot. The expressions of UII, GRP 78, CHOP, ALPHA-SMA, E-cadherin, fibronectin and type IV 


\section{Kidney \\ Blood Pressure Research}

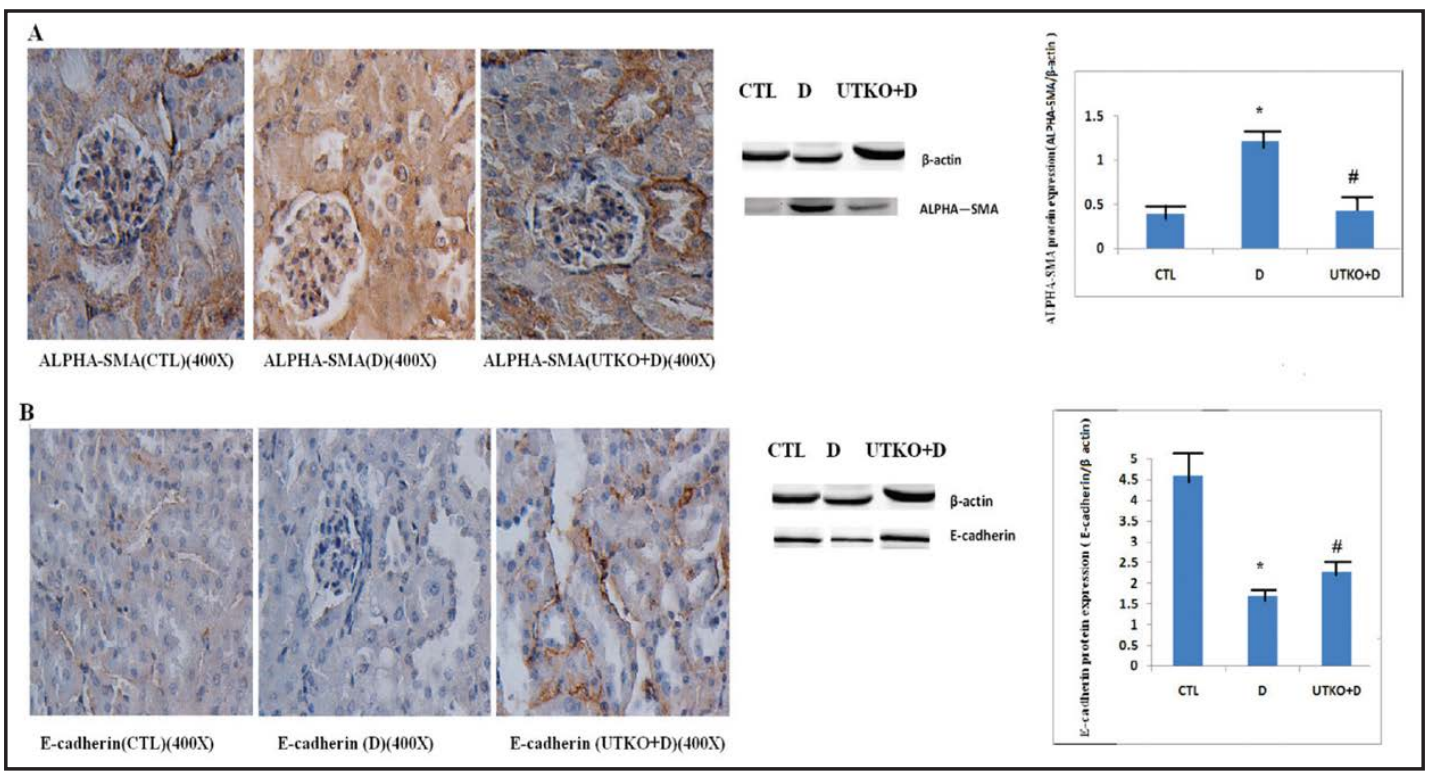

Fig. 5. Expressions of markers in kidney tissues. Expressions of ALPHA-SMA and E-cadherin were detected by immunochemistry and western blot analysis. CTL: normal control mice, D: wild type diabetic mice, UTKO+D: diabetic mice with UII receptor knock out. ${ }^{*} \mathrm{P}<0.01$ vs. CTL group; $\# \mathrm{P}<0.05$ vs. $\mathrm{D}$ group.

collagen were predominantly renal epithelium. Moreover, upregulated expressions of GRP 78, CHOP, ALPHA-SMA, fibronectin and type IV collagen in diabetic kidney tissues could be inhibited while down regulated expression E-cadherin was reversed in diabetes with UTKO+D group. We first verified UII receptor knock -out could downregulate ER Stress and EMT, and inhibit extracellular matrix (type IV collagen and fibronectin) production which are markers of renal fibrosis. But UII receptor knocked out did not inhibit UII expression in kidney tissue in UTKO+D group. UII induces ER stress and EMT and increases extracellular matrix production in renal tubular epithelial cell in early diabetes

\section{UII could induce ER stress and EMT of HK-2 cell in vitro}

By indirect immunofluorescent test in vitro, our results showed that there was no dose-dependent in HK-2 cells treated by UII in vitro study from UII $10^{-5}$ to $10^{-8} \mathrm{~mol} / \mathrm{L}$, but action of UII was disappeared at concentration of UII $10^{-9} \mathrm{~mol} / \mathrm{L}$, the most action of UII was at concentration $10^{-7} \mathrm{~mol} / \mathrm{L}$. So, UII $10^{-7} \mathrm{~mol} / \mathrm{l}$ were incubated with HK-2 for 24-48 hours. UII could enhance protein expression of ALPHA-SMA (figure 7.A), fibronectin (figure 7.C) and IV type collagen (figure 7.D) and decreased protein expression of E- cadherin (figure 7.B) (Image 400X laser scanning confocal microscope), and the up-regulated effect of UII on markers of EMT and fibronectin and IV type collagen in HK-2 cells could be inhibited by UII receptor antagonist SB657510 (figure7.A.B.C.D).

Western blot showed that markers of EMT such as ALPHA-SMA and FSP1 (figure 8.A.B); marker of ER Stress such as GRP 78 and CHOP protein expressions (figure 8. C.D) were increased in comparison to that of the control when UII $10^{-7} \mathrm{~mol} / \mathrm{l}$ were incubated with HK-2 for 24 hours, moreover, the upregulation of UII-induced markers of EMT and ER Stress in protein level could be inhibited by UII receptor antagonist treat (Figure 8, A, B, C, D).

When UII $10^{-7} \mathrm{~mol} / \mathrm{l}$ were incubated with HK-2 for 12-24 hours, mRNA expression of GRP78, CHOP (Figure 9, A and B), ALPHA-SMA and FSP1 (Figure 9.C.D) were significantly upregulated in comparison to that of the control, moreover, upregulation of ALPHA-SMA, FSP1, GRP78, CHOP mRNA induced by UII could be inhibited by UII receptor antagonist, suggesting that UII could initiate ER stress and EMT in mRNA level (Figure 9. A, B, C and D). 


\section{Kidney \\ Blood Pressure Research}

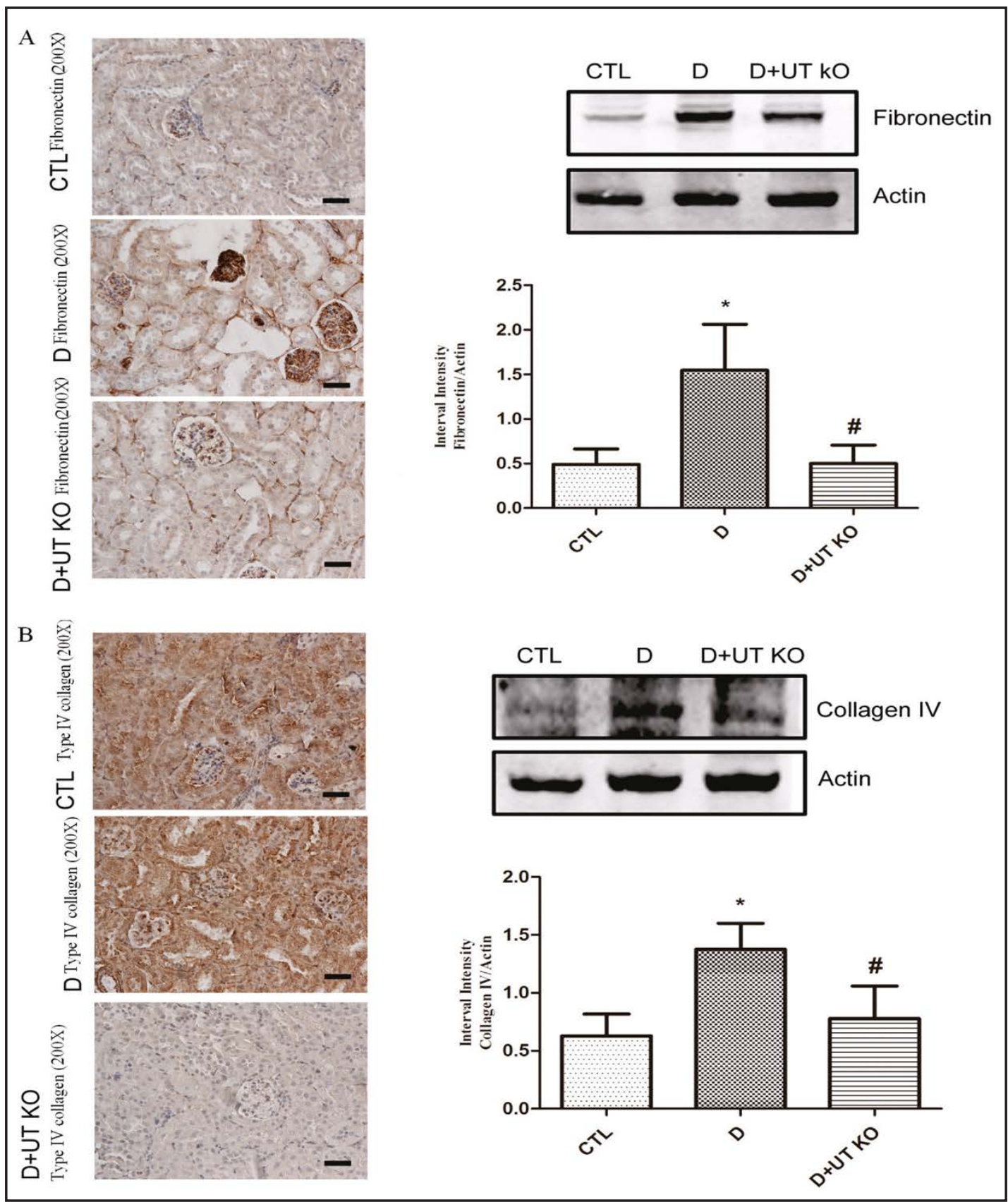

Fig. 6. Expressions of extracellular matrix in kidney tissues. Expressions of fibronectin (A) and type IV collagen (B) were detected by immunochemistry and western blot analysis. CTL: normal control mice (CTL), D: wild type diabetic mice (D), UTKO+D: diabetic mice with UII receptor knock out. ${ }^{*} \mathrm{P}<0.01$ vs. CTL group; $\# \mathrm{P}<0.05$ vs. D group.

UII induced EMT in HK cell via triggering ER stress pathway

We found that cell incubation of UII at $10^{-7} \mathrm{~mol} / \mathrm{l}$ for 24 hours can significantly increased ALPHA-SMA and FSP1 mRNA expression; however, the UII-induced up regulation of ALPHASMA and FSP1 mRNA expressions were significantly inhibited by co-incubation with the 4-PBA (ER stress suppressor) in HK-2 cells for 24 hours, $\mathrm{P}<0.05$; mRNA expression of CHOP and GRP78 were also decreased significantly, which suggest that 4-PBA could inhibit ER 


\section{Kidney Bloód Pressure Research}

\begin{tabular}{|c|c|}
\hline idney Blood Press Res & $34-449$ \\
\hline $\begin{array}{l}\text { DOI: } 10.1159 / 000443445 \\
\text { Published online: July } 13,2016\end{array}$ & $\begin{array}{l}\text { (c) } 2016 \text { The Author(s). Published by S. Karger AG, Basel } \\
\text { www.karger.com/kbr }\end{array}$ \\
\hline
\end{tabular}

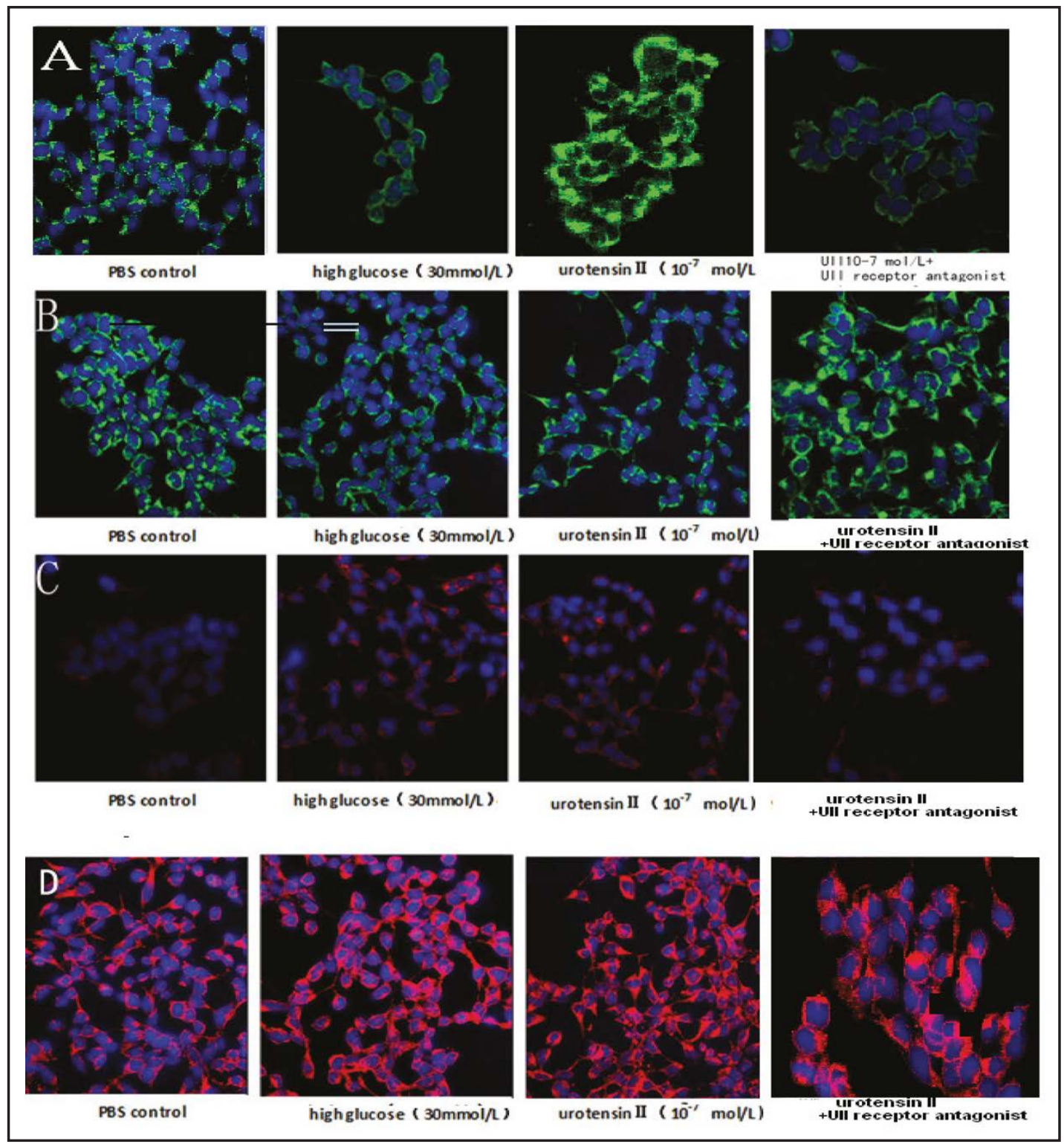

Fig. 7. Expressions of EMT and extracellular matrix in HK-2 cell. Expressions of ALPHA-SMA (A, color shown with green), E-cadherin (B, color shown with green), fibronectin (C, color shown with red) and type IV collagen (D, color shown with red) in HK-2 cell were shown after by UII, high glucose and UII combination with UII receptor antagonist treated and detected by indirect immunofluorescent methods. (Image 400X laser scanning confocal microscope).

stress caused by UII in HK- 2 cells, $\mathrm{P}<0.05$. When HK- 2 cells were treated by UII and 4-PBA $(1 \mathrm{mM})$ for 24 hours, FSP1 mRNA expression level decreased when compared with HK-2 cells that were treated with only UII for 24 hours. After incubating cells with 4-PBA (1mmol/L) for 12 hours and 24 hours, significant decrease of ALPHA-SMA level was observed when compared to that of the UII group with the maximum working effect at 24 hour (figure10), $\mathrm{P}<0.05$. This suggests that 4-PBA inhibit UII-induced EMT time-dependently. This indicates that ER stress pathway was involved in UII-induced EMT in HK-2 cells. We could not find the synergistic effect after UII combined high glucose compared with UII or high glucose alone (data not shown). 


\section{Kidney Blood Pressure Research}

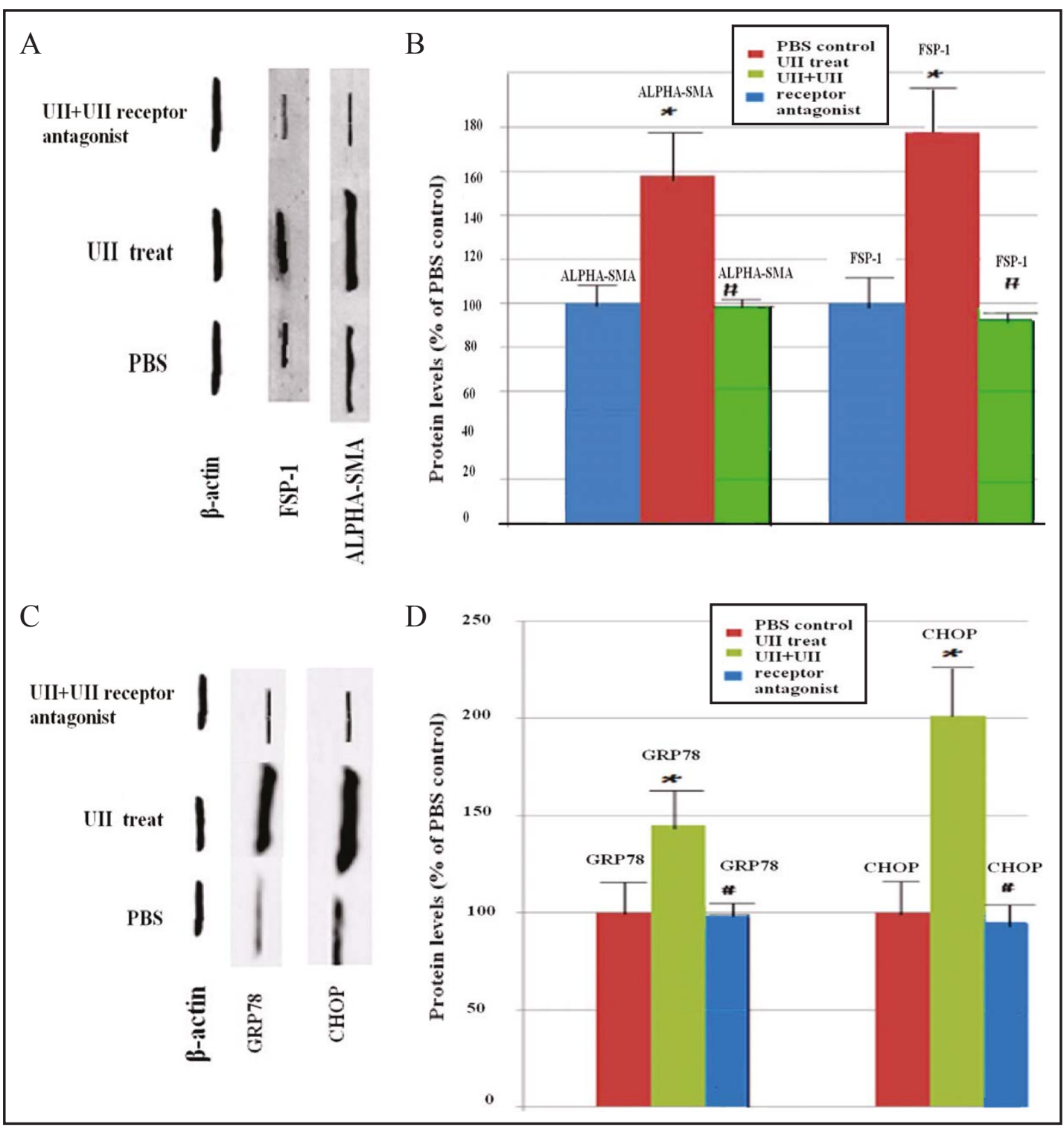

Fig. 8. Protein expressions of markers for EMT and ER Stress in HK-2 cell. Protein expressions of ALPHA-SMA and FSP1 (A and B), GRP 78 and CHOP (C and D) were detected by western blot analysis when UII $10^{-7} \mathrm{~mol} / \mathrm{l}$, UII+UII receptor antagonist were incubated with HK-2 for 24 hours, ${ }^{*} \mathrm{P}<0.05$ vs. PBS control, \# P $<0.05$ vs.UII treat.

\section{Discussion}

UII level is significantly increased in many kinds of diseases, such as hypertension, atherosclerosis, preeclampsia and diabetes [11-13]. However, previous studies mainly focused on the effects of UII on vascular activity. Recently, Tzanidis et al. revealed that UII also could stimulate cell proliferation, increase extracellular matrix, and induce myocardial fibrosis $[14,15]$. UII can induce cardiomyocyte to secrete type IV collagen and fibronectin after the TGF- $\beta 1$ signal pathway was blocked [16], this hints that there are some undiscovered mechanisms involved in the induction of myocardial fibrosis by UII.

In our previous study [17], we found that urinary UII was increased in DN patients compared with that of the healthy control. Additionally, urinary UII was positively correlated 


\section{Kidney Blood Pressure Research}

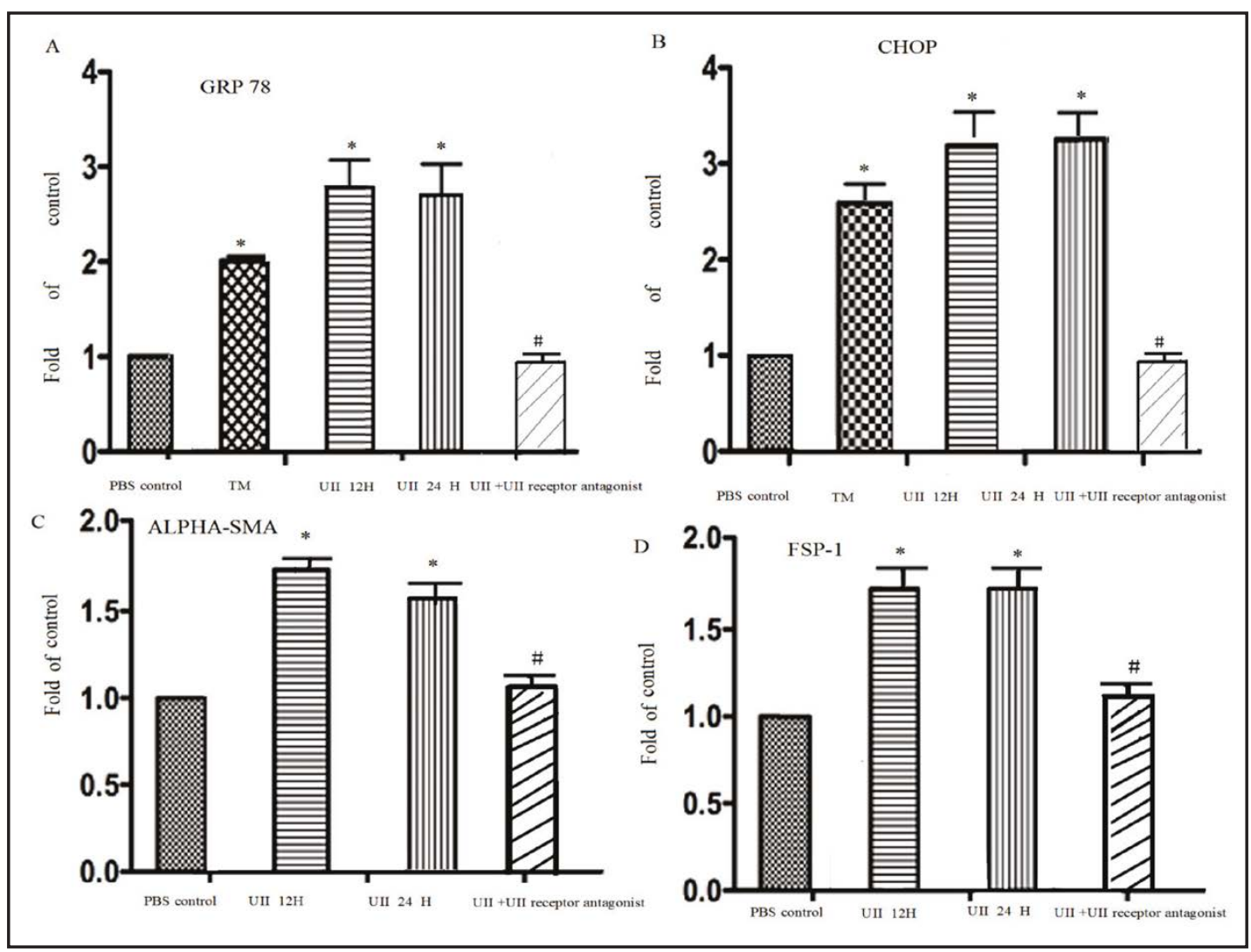

Fig. 9. mRNA expressions of markers for ER stress and EMT in HK-2 cell. mRNA expressions of GRP78 (A), CHOP (B). ALPHA-SMA (C) and FSP1 (D) were shown by real-time PCR after HK-2 cell treated by PBS, UII, TM (treated by tunicamycin, $25 \mathrm{ng} / \mathrm{ml}$ by ER Stress inducer) and UII +UII receptor antagonist. * $\mathrm{P}<0.05$ vs. normal control group, \#P<0.05 Vs. UII treat.

with the markers of renal tubule injury in DN. In our current study, expression of UII and GPR14 were increased in renal tubulointerstitium in patients' kidneys with DN, UII expression was negatively correlated with estimated glomerular filtration rate, and positively correlated with 24 proteinuria excretion, suggesting that UII might be related to renal tubule injury and interstitial fibrosis in DN. However, it is still unclear how UII contributes to tubulointerstitial injury and fibrosis in DN.

Lui and colleagues [18] studied the ER stress response in a mammalian model of diabetes, and they found increased expression of GRP78 in glomerular and tubular cells. Lindenmeyer, et al. also verified proteinuria and hyperglycemia induce

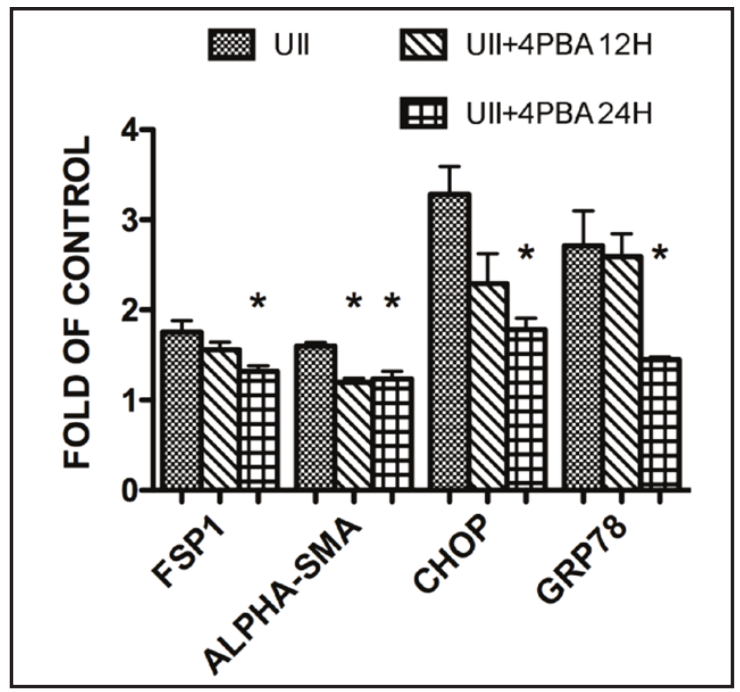

Fig. 10. Expression of markers for ER stress and EMT in HK-2 after treated by ER stress inhibitor. .mRNA expressions of FSP1, ALPHA-SMA, CHOP and GRP78 were detected after HK-2 cells were treated by UII, UII+4-PBA (ER stress inhibitor) for 12-hour and UII+4-PBA 24-hour. * $\mathrm{P}<0.05$ vs. UII-treated group. 


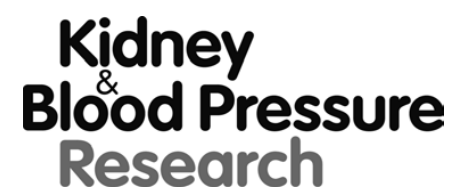

Kidney Blood Press Res 2016;41:434-449

\begin{tabular}{|l|l|}
\hline DOI: 10.1159/000443445 & (c) 2016 The Author(s). Published by S. Karger AG, Basel \\
\hline
\end{tabular}

Pang et al.: UII Associated with EMT and ER Stress

renal epithelial cell ER Stress in vitro [19]. In our study, markers of ER stress, GRP78 and CHOP were also found to be highly expressed in DN patients' kidney tissues, especially in renal tubular epithelium. Because the binding of UII with its receptors triggers phospholipidase $\mathrm{C}$ activation and inositol 1,4,5 triphosphate receptors-dependent pathway, which may induce release of calcium from endoplasmic-reticulum [9]. We speculate that UII may be correlated with ER Stress in its role in the development of DN. By diabetic model, we found that expression of UII is upregulated in kidney in early diabetes, accompanying with upregulation of ER Stress, EMT, fibronetin and type IV collagen. UT knock out did not affect UII expression in diabetes with UT knock out, but UII play roles depend on UT. We find that upregulation of ER Stress, EMT and extracellular matrix accumulation under diabetes are inhibited by UT gene knock out. We are the first to verify UII induces ER stress and EMT and increases extracellular matrix production in renal tubular epithelial cell in early diabetic mice (three weeks). Extracellular matrix is the markers of renal fibrosis which this suggests a potential role of UII and ER stress and EMT in the renal fibrosis of diabetes.

Then, we investigated whether UII can induce ER stress in renal tubular epithelial cells in vitro. In this study, we found that UII can enhance mRNA expression and GRP78 and CHOP protein, expressions in HK-2 cells, and this could be blocked by UII receptor antagonist who verifies that UII can induce ER stress in tubular epithelial cells in vitro. According to previous study $[1,2]$ and our current study, we speculate UII induce up regulation of mRNA and protein of GRP 78 and chop and not only may involve upstream signal of unfold protein response such as IRE, ATF 6 or PERK, but also may involve apoptosis pathway such as JNK, CHOP/GADD153 and Caspase12, we need the further investigation.

It is also well-known that EMT of renal tubular epithelial cell plays an important role in DN [20]. At present, it still remains unclear if the up regulation of renal UII in patients with DN is associated with EMT of renal tubular epithelial cell. Our results showed that exposure of HK-2 cells to UII can significantly increase protein and mRNA expression of the markers of EMT, such as ALPHA-SMA and FSP1; however, UII can inhibit expression of E- cadherin protein which is a marker of epithelial cell, and this could be blocked by UII receptor antagonist. ER stress is recently thought to be an important mechanism of EMT. It has been already verified that ER stress could induce EMT in thyroid gland cells and alveolar epithelial cells $[5,6]$ Src-dependent signaling was implicated in the link between ER stress and EMT. In order to verify whether UII induces EMT in renal tubular epithelial cell through ER stress pathway, we treated HK-2 cells with 4-PBA, a known antagonist of ER stress, and found that 4-PBA can inhibit the mRNA and protein expressions of ALPHA-SMA and FSP1 induced by UII in HK-2 cells. This means that UII can induce renal tubular epithelial EMT via triggering ER stress in HK-2 cell in vitro and this is consistent with our in vitro study in vivo.

In diabetic nephropathy, we believe under the stimulation of specific environments (high glucose, increase of urinary UII and proteinuria) renal tubular epithelial cells undergo EMT process becoming myofibroblasts, which are the primary sources of extracellular matrix in renal cells, contributing to the development of renal fibrosis. Whether UII induced EMT via ER stress involve Smad2/Smad3, Src, and Wnt/ $\beta$-catenin pathways, we need further study.

Tian [12], et al. reported that diabetes-induced upregulation of urotensin II and its receptor played an important role in TGF- $\beta 1$-mediated renal fibrosis and dysfunction, besides this, NF- $\kappa \mathrm{B}$ and hypoxia inducible factor- $1 \alpha$ signals are also associated with EMT of in renal tubular epithelial cell $[21,22]$ TGF- $\beta 1$, connective tissue growth factor and tumor necrosis factor $\alpha$ are associated with renal fibrosis [21,22]. We need further study whether UII still induce renal tubular epithelial cell EMT after we blocked TGF- $\beta 1$ signal, NF- $\kappa B$ and HIF-1a signal. Moreover, we need further investigate relation of UII to the fibrotic pathway protein such as TGF- $\beta 1$, connective tissue growth factor and tumor necrosis factor $\alpha$.

Recently, authors investigated some new strategies in animal experiments for treatment of DN. Dschietzig, et al. [23] reported that relaxin-2 does not ameliorate nephropathy in an experimental model of type-1 diabetes whereas Eren, et al [24] verified a potential role of 


\section{Kidney Blood Pressure Research}

aliskiren plus paricalcitol acting synergystically for reducing the progression of diabetic nephropathy in an experimental rat model.

Previous studies [25] showed that infusion of synthetic rat UII inhibited glucoseinduced insulin release in a dose-dependent manner, so we speculate that under diabetes, high glucose combined UII may have an additive or synergy effect on the ER stress and EMT in the proximal tubule cells in vitro, but we could not find the synergistic effect after UII combined high glucose compared with UII or high glucose alone (data not shown). Tian, et al. [12] reported that exposure of rat renal epithelial cells to TGF-beta1 or ANG II also increased UII and UII receptor mRNA expressions, we did not study high glucose induces UII expression in tubular epithelial cells in vitro. But in our vivo study, we found down regulation for expressions of ER stress and EMT in diabetic mice with UII receptor knock out in comparison to those of kidney tissue in wild type diabetic mice, it is seem that inhibition of the endogenous UII leads to a reduction of ER stress and EMT in glucose-treated cells.

The present study has some limitations. The size of clinical samples is small. Moreover, it is also crucial to study the signaling pathways for the induction of ER stress and EMT in renal tubular epithelium by UII.

\section{Conclusion}

We are the first to verify UII induces ER stress and EMT and increases extracellular matrix production in renal tubular epithelial cell in early diabetic kidney. UII may induce renal tubular epithelial EMT via triggering ER stress pathway in vitro, which might be the new pathogenic pathway for the development of renal fibrosis in diabetic nephropathy.

\section{Disclosure Statement}

The authors report no conflict of interest. The authors alone are responsible for the content and writing of this paper.

\section{Acknowledgements}

This study was supported by National Natural Science Foundation (Grant No. 81170706, Grant No 81341022, Grant No 81570663) to AH Zhang.

\section{Reference}

1 Arora MK, Singh UK: Molecular mechanisms in the pathogenesis of diabetic nephropathy: an update. Vascul Pharmacol 2013;58:259-271.

2 Inagi R: Endoplasmic reticulum stress in the kidney as a novel mediator of kidney injury. Nephron Exp Nephrol 2009;112:e1-e9.

3 Cao Y, Hao Y, Li H, Liu Q, Gao F: Role of endoplasmic reticulum stress in apoptosis of differentiated mouse podocytes induced by high glucose. Int J Mol Med 2014;33:809-816.

4 Fang L, Xie D, Wu X, Cao H, Su W: Involvement of endoplasmic reticulum stress in albuminuria induced inflammation some activation in renal proximal tubular cells. PLoS One 2013;20:e72344.

5 Ulianich L, Garbi C, Treglia AS, Punzi D, Miele C: ER stress is associated with dedifferentiation and an epithelial-to-mesenchymal transition-like phenotype in PC Cl3 thyroid cells. J Cell Sci 2008;121:477-486. 


\section{Kidney \\ Blood Pressure Research}

6 Zhong Q, Zhou B, Ann DK, Minoo P, Liu Y: Role of endoplasmic reticulum stress in epithelial-mesenchymal transition of alveolar epithelial cells: effects of misfolded surfactant protein. Am J Respir Cell Mol Biol 2011;45:498-509.

7 Ames RS, Sarau HM, Chambers JK, Willette RN, Aiyar NV: Human urotensin-II is a potent vasoconstrictor and agonist for the orphan receptor GPR14. Nature 1999;401:282-286.

8 Langham RG, Kelly DJ, Gow RM, Zhang Y, Dowling JK: Increased expression of urotensin II and urotensin II receptor in human diabetic nephropathy. Am J Kidney Dis 2004;44:826-831.

9 Jarry M, Diallo M, Lecointre C: The vasoactive peptides urotensin II and urotensin II-related peptide regulate astrocyte cell activity through common and distinct mechanisms: involvement in cell proliferation. Biochem J 2010;428:113-124.

10 Mekahli D, Bultynck G, Parys JB, De Smedt H, Missiaen L: Endoplasmic-reticulum calcium depletion and disease. Cold Spring Harb Perspect Biol 2011;3:a004317.

11 Thanassoulis G, Huyhn T, Giaid A: Urotensin II and cardiovascular diseases. Peptides 2004;25:1789-1794.

12 Tian L, Li C, Qi J, Fu P, Yu X: Diabetes-induced upregulation of urotensin II and its receptor plays an important role in TGF-beta1-mediated renal fibrosis and dysfunction. Am J Physiol Endocrinol Metab 2008;295:E1234-E1242.

13 He WY, Chen GJ, Lai X, Wu F, Tang CS, Zhang AH: Expression levels of urotensin II are associated with endoplasmic reticulum stress in patients with severe preeclampsia. J Hum Hypertens 2016;30:129-135.

14 Tzanidis A, Hannan RD, Thomas WG, Onan D, Autelitano DJ: Direct actions of urotensin II on the heart: implications for cardiac fibrosis and hypertrophy. Circ Res 2003;93:246-253.

15 Zhang YG, Li YG, Liu BG, Wei RH, Wang DM: Urotensin II accelerates cardiac fibrosis and hypertrophy of rats induced by isoproterenol. Acta Pharmacol Sin 2007;28:36-43.

16 Dai HY, He T, Li XL, Xu WL, Ge ZM: Urotensin-2 promotes collagen synthesis via ERK1/2-dependent and ERK1/2-independent TGF- $\beta 1$ in neonatal cardiac fibroblasts. Cell Bio Int 2011;35:93-98.

17 He WY, Bai Q, A LT, Tang CS Zhang AH: Irisin levels are associated with urotensin II levels in diabetic patients . J Diabetes Invest 2015;6:571-576.

18 Liu G, Sun Y, Li Z, Song T, Wang H: Apoptosis induced by endoplasmic reticulum stress involved in diabetic kidney disease. Biochem Biophys Res Commun 2008;370:651-656.

19 Lindenmeyer MT, Rastaldi MP, Ikehata M, Neusser MA, Kretzler M: Proteinuria and hyperglycemia induce endoplasmic reticulum stress. J Am Soc Nephrol 2008;19:2225-2236.

20 Hills CE, Squires PE: TGF-beta1-induced epithelial-to-mesenchymal transition and therapeutic intervention in diabetic nephropathy. Am J Nephrol 2010;31:68-74.

21 Du R, Xia L, Ning X, Liu L, Sun W: Hypoxia-induced Bmi1 promotes renal tubular epithelial cellmesenchymal transition and renal fibrosis via PI3K/Akt signal. Mol Biol Cell 2014;25:2650-2659.

22 Elsa SL, Sandra R, Raquel RD, Javier SR, Raul RD: CTGF Promotes Inflammatory Cell Infiltration of the Renal Interstitium by Activating NF-кB. J Am Soc Nephrol 2009;20:1513-1526.

23 Dschietzig TB, Krause-Relle K, Hennequin M, von Websky K, Rahnenführer J, Ruppert J, Grön HJ, Armbruster FP, Bathgate RA, Aschenbach JR, Forssmann WG, Hocher B: Relaxin-2 does not ameliorate nephropathy in an experimental model of type-1 diabetes. Kidney Blood Press Res 2015;40:77-88.

24 Eren Z, Günal MY, Bakir EA, Coban J, Çağlayan B, Ekimci N, Ethemoglu S, Albayrak O, Akdeniz T, Demirel GY, Kiliç E, Kantarci G: Effects of paricalcitol and aliskiren combination therapy on experimental diabetic nephropathy model in rats. Kidney Blood Press Res 2014;39:581-590.

25 Silvestre RA, Egido EM, Hernandez R, Leprince J, Chatenet D: Urotensin-II is present in pancreatic extracts and inhibits insulin release in the perfused rat pancreas. Eur J Endocrinol 2004;151:803-809. 